\title{
PELATIHAN PERHITUNGAN HARGA POKOK PRODUKSI, HARGA JUAL DAN STRATEGI PEMASARAN BAGI PERAJIN TAS RANSEL DI DESA SANGKAN HURIP KABUPATEN BANDUNG
}

\author{
Hery Sayerul Homan \\ hery.syaerul@ekuitas.ac.id \\ Deni Hamdani \\ dnhamdani34@gmail.com \\ Siska Willy \\ siska_msws@yahoo.com
}

\section{SEKOLAH TINGGI ILMU EKONOMI EKUITAS}

\begin{abstract}
ABSTRAK
Pelatihan perhitungan biaya produksi, penetapan harga jual dan strategi pemasaran ini ditujukan untuk memberikan pemahaman kepada mitra dalam menghitung biaya produksi berdasarkan pesanan, menentapkan harga jual dan menerapakan strategi pemasaran yang tepat. Lokasi pelatihan dilakukan di tempat usaha perajin tas ransel di Desa Sangkan Hurip Kabupaten Bandung Jawa Barat. Pelatihan ini dilakukan dengan menggunakan metode ceramah dan studi kasus terapan sebanyak 8 sesi pelatihan pada bulan Februari hingga Maret 2020 dengan durasi 90 menit setiap sesinya. Peserta pelatihan diajarkan materi mengenai konsep dasar biaya dan klasifikasinya, perhitungan biaya produksi berdasarkan pesanan, metode dalam penetapan harga jual dan strategi pemasaran yang dapat diterapkan oleh mitra dalam menjalankan usahanya. Pelatihan berhasil diikuti oleh mitra hingga selesai dengan tingkat pemahaman yang baik berdasarkan evaluasi pada post-test yang dilaksanakan di setiap pertemuan. Penulis menyarankan agar mitra dapat menerapkan hasil pelatihan ini secara konsisten sehingga dapat mengetahui besarnya laba-rugi yang diperoleh serta dapat meningkatkan usahanya dengan menerapakan strategi pemasaran yang tepat.
\end{abstract}

Kata kunci: Cost, Pemasaran, Pricing.

\section{PENDAHULUAN}

Peran Usaha Mikro, Kecil dan Mengengah (UMKM) bagi perekonomian Indonesia begitu nyata. Hal ini diperkuat berdasarkan publikasi Kementrian Koperasi dan Usaha Kecil dan Menengah (Kemenkop, 2020) yang bersumber dari Badan Pusat Statisik bahwa unit usaha mikro, kecil dan menengah memiliki kontribusi sebesar $60,9 \%$ dari total Produk Domestik Bruto Indonesia pada tahun 2018. Selain itu, UMKM mampu menyerap 97\% dari total tenaga kerja. Data menunjukkan bahwa sampai dengan tahun 2018, UMKM berjumlah 64.199.606 (BPS, 2020). Namun demikian, penyebaran virus corona (Covid19) memukul perekonomian Indonesia, termasuk pelaku usaha. Kementrian Keuangan mencatat, pelaku usaha yang 
terdampak signifikan adalah UMKM. Menteri Koperasi dan Usaha Kecil Menengah (Kemenkop) mengatakan bahwa terdapat 1.785 koperasi dan 16.313 KUKM yang terdampak pandemi Covid-19 (Kontan, 2020).

Merujuk pada Profil Industri Mikro dan Kecil (BPS, 2019) sebesar 62,26\% jumlah usaha industri mikro dan kecil tahun 2019 berada di pulau Jawa, dimana Jawa Tengah merupakan Provinsi dengan jumlah usaha terbanyak yaitu sebanyak 912.000 usaha. Menurut Undang-undang No. 20 Tahun 2008, usaha mikro memiliki kekayaan paling banyak Rp50.000.000 tidak termasuk tanah dan bangunan tempat usaha sedangkan usaha kecil memiliki kekayaan bersih lebih dari Rp50.000.000 dengan paling banyak Rp500.000.000 tidak termasuk tanah dan bangunan tempat usaha. Selain itu, untuk membedakan industri mikro dan kecil dapat dilihat dari jumlah tenaga kerjanya. Industri mikro memiliki tenaga kerja 1-4 orang sedangkan industri kecil memiliki tenaga kerja 5-19 orang.

Berbagai daerah di Indoesia terus mengembangkan UMKM termasuk di Kabupaten Bandung. Desa Sangkan Hurip merupakan salah satu Desa di Kecamatan Katapang Kabupaten Bandung yang memiliki area terluas yaitu $20,17 \%$ terhadap luas kecamatan (BPS Kecamatan Katapang, 2020) dan berjarak $6 \mathrm{~km}$ dari Ibu Kota Kabupaten. Desa ini juga memiliki jumlah industri rumah tangga terbesar kedua di Kecamatan Katapang yaitu terdapat 87 industri rumah tangga dari total 277 industri rumah tangga yang ada di Kecamatan Katapang. Industri rumah tangga yang saat ini berkembang di Desa Sangkan Hurip diantaranya pembuatan sangkar burung, makanan tradisional, makanan ringan, tas ransel, roti, topi, jasa service elektronik, jasa menjahit dan sejenisnya.

Produksi tas ransel merupakan salah satu usaha yang bergerak dibidang manufaktur atau produksi. Dalam menjalankan usahanya mitra ini menghadapi kendala. Kendala utama yang dihadapi secara umum oleh pelaku UMKM yaitu kendala menjalankan usaha, modal, dan memperoleh bahan baku (BPS, 2019). Salah satu kendala yang paling sering dihadapi oleh para pelaku usaha ini adalah masalah pencatatan dan penyusunan laporan keuangan (Agustina et al., 2019; Ardillah, 2020; Machfuzhoh et al., 2020), Hal ini dapat dipahami karena tidak semua pelaku bisnis usaha mikro memiliki latar belakang dan kemampuan di bidang akuntansi, sedangkan jika harus memperkerjakan seorang akuntan masih belum mampu secara finansial (Machfuzhoh et al., 2020).

Sama halnya dengan pelaku UMKM pada umumnya, mitra pada pengabdian ini pun menghadapi berbagai kendala telebih pada saat pandemi Covid-19 ini. Selama ini, tas ransel diproduksi berdasarkan pesanan dari toko yang ada di daerahnya. Harga yang diterapkan berdasarkan harga pasar yang diminta oleh pihak toko. Masalah pertama yang dihadapi mitra yaitu tidak pernah menghitung secara tepat berapa biaya produksi per tas ransel yang dibuatnya. Hal ini tentu berdampak dalam menentukan harga jual. Dampak lainnya yaitu tidak dapat diketahui keuntungan yang diperoleh dari hasil penjualan tas tersebut.

Biaya produksi adalah biaya yang terjadi untuk mengubah bahan baku menjadi barang jadi (Siregar et al., 2013). Dengan demikian tiga unsur dari biaya produksi terdiri dari biaya bahan baku langsung, tenaga kerja langsung, dan biaya overhead (Riwayadi, 2016). Ketiga komponen ini kemudian dijumlahkan untuk mendapatkan total biaya produksi. Untuk mendapatkan biaya per unit maka total biaya produksi dibagi dengan jumlah unit yang diproduksi (quantity). Dengan disusunnya informasi biaya produksi maka bermanfaat untuk 1) menentukan harga jual yang akan dibebankan kepada pemesan, 2) memperhitungkan penerimaan atau penolakan pesanan, 3) memantau realisasi biaya produksi, 4) menghitung laba atau rugi setiap pesanan, dan 5) menentukan harga jual dengan biaya produksi (Ramdani et al., 2020) 
Masalah kedua yang dihadapi mitra yaitu belum mampu menetapkan harga jual. Keputusan penetapan harga jual merupakan keputusan yang tidak mudah. Pelaku usaha dihadapkan pada keraguan, apakah harga jual yang ditetapkan dapat diterima oleh pasar sekaligus juga memberikan keuntungan secara finansial. Menurut Rudianto (2013) penetapan harga jual memerlukan berbagai pertimbangan yang terintegrasi, mulai dari biaya produksi, biaya operasional, harga jual pesaing, kondisi perekonomian secara umum, dan elastisitas harga produk.

Masalah berikutnya yang dihadapi oleh pelaku UMKM yaitu mengenai pemasaran. Selama ini produksi hanya mengandalkan pesanan dari toko daerah sekitarnya. Sehingga, ketika tidak ada pesanan dari toko maka tidak ada aktivitas produksi. Terlebih pada masa pandemi ini, ketika permintaan dari toko menurun maka dampaknya terasa pada menurunnya aktivitas produksi.

Pada umumnya pemasaran dipersepsikan sama dengan penjualan atau promosi, padahal penjualan atau promosi hanyalah bagian kecil dari pemasaran (Saleh \& Said, 2019). Tujuan pemasaran yaitu untuk menarik perhatian pembeli dalam mengkonsumsi produk yang ditawarkan, oleh karena itu pemasaran berperan penting dalam mengembangkan strategi (Saleh \& Said, 2019). Strategi pemasaran dapat memberikan gambaran yang jelas dan terarah tentang apa yang akan dilakukan perusahaan dalam menggunakan setiap kesempatan atau peluang pada beberapa pasar sasaran (Assauri, 2015).

Ketiga permasalahan di atas dapat diatasi dengan memberikan pelatihan perhitungan biaya produksi, penetapan harga jual dan strategi pemasaran (Herlina, 2021; Purwanto et al., 2020). Dengan diberikannya pelatihan diharapkan dapat terjadi peningkatan pemahaman sehingga mitra dapat menghitung biaya produksi, menetapkan harga jual dan menerapkan strategi pemasaran yang tepat.

\section{METODOLOGI PELAKSANAAN}

Kegiatan pelatihan perhitungan biaya produksi, menetapkan harga jual dan strategi pemasaran ini dilakukan pada mitra yang memproduksi tas ransel di Desa Sangkan Hurip Kecamatan Katapang Kabupaten Bandung Provinsi Jawa Barat. Usahanya termasuk usaha mikro karena memperkerjakan sampai dengan 4 orang.Kegiatan pengabdian ini dilakukan oleh dua dosen akuntansi dan satu dosen pemasaran Sekolah Tinggi Ilmu Ekonomi EKUITAS. Alur tahapan kegiatan pengabdian dapat dilihat pada gambar di bawah ini.

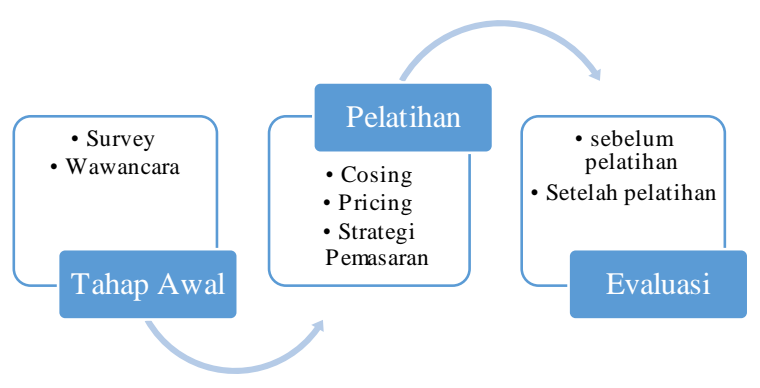

Gambar 1. Alur Tahapan Kegiatan
Pengabdian

Pada tahap awal kegiatan, penulis melalukan survey dan wawancara di kantor Desa Sangkan Hurip untuk memperoleh informasi mengenai kegiatan industri rumah tangga yang ada di Desa Sangkan Hurip. Wawancara pun dilanjutkan di lokasi salah satu UMKM yaitu perajin tas ransel. Kegiatan awal ini dilaksanakan pada bulan Oktober 2019 dengan durasi waktu 4 jam.

Pelaku usaha mikro yang menjadi mitra pada kegiatan ini yaitu Bapak Maman. Beliau menjalankan usaha pembuatan tas ransel bersama istrinya dan dua orang karyawan. Kegiatan usahanya merupakan kegiatan yang diturunkan dari keluarga orang tuanya dan telah berlangsung selama 6 tahun.

Tahap pelatihan merupakan tahap pelaksanaan dari kegiatan pengabdian. Pelatihan dilaksanakan pada bulan Februari hingga Maret 2020. Pelatihan ini didesain menjadi 8 sesi, dimana terdiri dari 4 sesi 
teori dan 4 sesi praktik. Satu sesi berlangsung 90 menit. Sehingga total pelatihan selama 12 jam. Waktu pelaksanaan dilakukan seminggu sekali selama 4 kali dengan kesepakatan waktu pada jam dimana tidak mengganggu waktu produksi. Setiap kali pertemuan terdiri dari sesi teori dan sesi praktik.

Pelatihan ini dilaksanakan dengan memadukan unsur teori dan praktik. Hal ini ditujukan untuk lebih meningkatkan pemahaman mitra. Konsep teori diberikan dengan menggunakan metode ceramah dimana pemateri menjelaskan dengan bantuan mediahand-out dan mitra memperhatikan penjelasan dari pemateri. Pada sesi berikutnya dilakukan praktik dari penjelasan teori sebelumnya. Pada praktik ini pemateri menyiapkan soal kasus yang relevan dengan karakteristik usaha mitra. Pemateri membimbing dan memberikan tanggapan atas hasil yang telah dikerjakan oleh mitra. Diakhir setiap pertemuan dilakukan post-test untuk mengetahui tingkat pemahaman mitra terhadap materi yang telah diberikan.

Tahap terakhir yaitu tahap evaluasi. Pada tahap ini dilakukan penilaian terhadap pemahaman mitra. Penulis memeriksa dan merekap keseluruhan hasil post-test yang telah dikerjakan oleh mitra. Jika hasil ratarata post-test diperolah dengan nilai minimm 70, maka mitra dinyatakan lulus.

\section{HASIL DAN LUARAN}

Pada bulan Februari sampai dengan Maret 2020, penulis telah melakukan pelatihan perhitungan biaya produksi, penetapan harga jual dan strategi pemasaran. Pelatihan ini dilaksanakan dalam 4 kali pertemuan. Pada setiap pertemuan terdiri dari sesi penjelasan teori dan sesi praktik dengan durasi masing-masing 90 menit, sehingga total per pertemuan adalah 180 menit.

Pada pertemuan 1 diberikan materi mengenai konsep dasar biaya dan klasifikasi biaya produksi. Hal ini ditujukan untuk membekali mitra dengan konsep yang menjadi dasar materi pada pertemuan berikutnya. Pemahaman mitra mengenai klasifikasi biaya produksi selama ini kurang tepat, karena hanya memasukkan biaya bahan dan biaya tenaga kerja saja. Setelah mengikuti pelatihan pada pertemuan 1, mitra telah mampu menjelaskan mengenai konsep biaya dan mengklasifikasikan berbagai jenis biaya produksi menjadi biaya bahan baku langsung, tenaga kerja langsung, dan biaya overhead.

Materi yang diberikan pada pertemuan kedua yaitu mengenai perhitungan biaya produksi berdasarkan pesanan (job order costing). Mitra diajarkan proses aliran biaya dalam sistem pesanan, membuat kartu pesanan, menghitung harga pokok produksi berdasarkan pesanan dan menghitung labarugi. Materi ini disampaikan dengan menunjukkan contoh sederhana yang terjadi pada produksi tas ransel. Tujuannya supaya materi yang disampaikan dapat lebih dipahami dengan mudah. Pada sesi praktik, mitra diberikan soal kasus terapan dan diberikan kesempatan untuk menyelesaikannya. Kemudian pemateri memberikan tanggapan dan bimbingan untuk melakukan perbaikan jika diperlukan.

Materi pada pertemuan ketiga yaitu penetapan harga (pricing). Materi yang diberikan yaitu penetapan harga berdasarkan harga pokok produksi penuh (cost-plus), berdasarkan laba yang ditargetkan, dan berdasarkan elastisitas harga. Pada sesi praktik diberikan studi kasus terapan dari masing-masing metode penetapan harga.

Materi yang diberikan pada pertemuan keempat yaitu mengenai strategi pemasaran. Pembahasan dimulai dari konsep sederhana mengenai pemasaran, implementasi strategi pemasaran meliputi segmentation, targeting, dan positioning. Selain itu diberikan juga materi mengenai promosi. Pada sesi praktik, diberikan soal kasus terapan mengenai strategi pemasaran serta diskusi mengenai strategi pemasaran yang tepat untuk produksi tas ransel.

Setiap akhir pertemuan dilakukan posttest dengan waktu sekitar 15 menit. Hal ini 
dilakukan untuk mengetahui tingkat pemahaman dari materi yang telah diberikan. Dari keempat hasil post-test mitra mendapatkan nilai rata-rata diatas 70 . Dengan demikian dapat dikatakan mitra telah memahami materi yang diberikan selama pelatihan. Pada tabel di bawah ini digambarkan kondisi sebelum dan setelah mengikuti pelatihan pada masing-masing pertemuan.

Tabel. 1. Hasil Evaluasi Setelah Pelatihan

\begin{tabular}{|c|c|c|}
\hline $\begin{array}{c}\text { Materi } \\
\text { Pelatihan }\end{array}$ & $\begin{array}{c}\text { Kondisi } \\
\text { Sebelum } \\
\text { Pelatihan }\end{array}$ & $\begin{array}{c}\text { Evaluasi } \\
\text { Setelah } \\
\text { Pelatihan }\end{array}$ \\
\hline $\begin{array}{l}\text { Konsep } \\
\text { dasar } \\
\text { biaya dan } \\
\text { klasifikas } \\
\text { i biaya } \\
\text { produksi }\end{array}$ & $\begin{array}{l}\text { Mitra } \\
\text { belum } \\
\text { memaham } \\
\text { i } \\
\text { mengenai } \\
\text { konsep } \\
\text { biaya } \\
\text { produksi. } \\
\text { Biaya } \\
\text { produksi } \\
\text { menurut } \\
\text { mitra } \\
\text { terdiri dari } \\
\text { biaya } \\
\text { bahan dan } \\
\text { tenaga } \\
\text { kerja. }\end{array}$ & $\begin{array}{l}\text { Mitra telah } \\
\text { memahami } \\
\text { konsep biaya, } \\
\text { komponen } \\
\text { biaya produksi } \\
\text { dan } \\
\text { mengklasifikasi } \\
\text { kan jenis biaya } \\
\text { ke dalam biaya } \\
\text { bahan baku } \\
\text { langsung, } \\
\text { tenaga kerja } \\
\text { langsung, dan } \\
\text { biaya overhead }\end{array}$ \\
\hline $\begin{array}{l}\text { Perhitung } \\
\text { an biaya } \\
\text { berdasark } \\
\text { an } \\
\text { pesanan }\end{array}$ & $\begin{array}{l}\text { Mitra } \\
\text { belum } \\
\text { memaham } \\
\text { i } \\
\text { perhitunga } \\
\text { n biaya } \\
\text { produksi } \\
\text { berdasark } \\
\text { an } \\
\text { pesanan }\end{array}$ & $\begin{array}{l}\text { Mitra telah } \\
\text { memahami } \\
\text { perhitungan } \\
\text { biaya produksi } \\
\text { berdasarkan } \\
\text { pesanan }\end{array}$ \\
\hline $\begin{array}{l}\text { Penetapa } \\
\mathrm{n} \text { harga } \\
\text { jual }\end{array}$ & $\begin{array}{l}\text { Mitra } \\
\text { belum } \\
\text { memaham } \\
\text { i cara } \\
\text { perhitunga } \\
\mathrm{n} \text { harga } \\
\text { jual } \\
\text { berdasaka } \\
\mathrm{n} \text { pesanan }\end{array}$ & $\begin{array}{l}\text { Mitra mampu } \\
\text { melakukan } \\
\text { perhitungan } \\
\text { harga jual } \\
\text { dengan } \\
\text { menggunakan } \\
\text { metode } \\
\text { berdasarkan } \\
\text { biaya produksi, }\end{array}$ \\
\hline
\end{tabular}

\begin{tabular}{|l|l|l|}
\hline $\begin{array}{c}\text { Materi } \\
\text { Pelatihan }\end{array}$ & $\begin{array}{l}\text { Kondisi } \\
\text { Sebelum } \\
\text { Pelatihan }\end{array}$ & $\begin{array}{c}\text { Evaluasi } \\
\text { Setelah } \\
\text { Pelatihan }\end{array}$ \\
\hline & & $\begin{array}{l}\text { berdaarkan laba } \\
\text { yang } \\
\text { ditargetkan, dan } \\
\text { berdasarkan } \\
\text { elastisitas } \\
\text { harga. }\end{array}$ \\
\hline $\begin{array}{l}\text { Strategi } \\
\text { pemasara } \\
\text { n }\end{array}$ & $\begin{array}{l}\text { Mitra } \\
\text { belum } \\
\text { menerapk } \\
\text { an strategi } \\
\text { pemasaran } \\
\text { dalam } \\
\text { menjalank } \\
\text { an } \\
\text { usahanya }\end{array}$ & $\begin{array}{l}\text { Mitra memahami } \\
\text { strategi } \\
\text { pemasaran dan } \\
\text { menyusun } \\
\text { strategi untuk } \\
\text { menjalankan } \\
\text { usahanya. }\end{array}$ \\
\hline
\end{tabular}

\section{KESIMPULAN DAN SARAN}

Berdasarkan evaluasi yang dilakukan pada kegiatan pelatihan perhitungan biaya produksi, penetapan harga jual, dan strategi pemasaran, maka dapat disimpulkan sebagai berikut:

1. Mitra telah berhasil mengikuti pelatihan dan telah memahami perhitungan biaya produksi dan penetapan harga jual. Penulis menyarankan agar mitra secara konsisten menerapkan perhitungan biaya berdasarkan pesanan dan menetapkan harga jual, sehingga dapat diketahui jumlah laba-rugi dari pesanan yang telah diproduksi.

2. Mitra telah memahami mengenai strategi pemasaran yang dapat diterapkan pada usahanya. Penulis menyarankan mitra dapat menerapkannya secara konsisten sehingga dapat dikenal oleh lebih banyak calon konsumen. Dengan demikian, pesanan dapat terus diterima sehingga produksi dapat terjaga keberlanjutannya.

\section{DAFTAR PUSTAKA}

Agustina, Y., Setianingsih, S., \& Santoso, Y. D. (2019). Pelatihan Penyusunan 
Laporan Keuangan Bagi Entitas Mikro, Kecil, dan Menengah Bidang Usaha Dagang pada UMKM Binaan Pusat Inkubasi Bisnis Syariah Majelis Ulama Indonesia. Jurnal Pengabdian Masyarakat: Intervensi Komunitas, Vol. 1(1), 1-15. http://ojs.itbad.ac.id/index.php/IK/article/view/24 2\%0Ahttp://ojs.itbad.ac.id/index.php/IK/article/view/24 $2 / 170$

Ardillah, K. (2020). Pelatihan Aplikasi Akuntansi Bagi Pelaku Usaha Mikro, Kecil, dan Menengah Di Banten. Jurnal Dharma Bhakti Ekuitas, 05(01), 472-482.

Assauri, S. (2015). Manajemen Pemasaran. Jakarta: Rajawali Pers.

BPS. (2019). Profil Industri Mikro dan Kecil. Jakarta: Badan Pusat Statistik

BPS. (2020). Kecamatan Katapang Dalam Angka. Bandung: Badan Pusat Statistik Kabupaten Bandung.

Herlina, E. (2021). Peningkatan Kemampuan Wirausaha Dengan Pendampingan dan Pemberdayaan Kelompok Usaha Sablon "SALAM" Melalui Strategi Pemasaran Modern dan Job Order Costing. Jurnal Kemitraan Dan Pemberdayaan Masyarakat, 1(1), 25-34.

Kemenkop. (2020). Perkembangan Data Usaha Mikro , Kecil, Menengah Dan Usaha Besar. http://www.depkop.go.id/uploads/lap oran/1580223129_PERKEMBANGA N DATA USAHA MIKRO, KECIL, MENENGAH (UMKM) DAN USAHA BESAR (UB) TAHUN 2017 - 2018.pdf

Machfuzhoh, A., . L.-, \& Widyaningsih, I. U. (2020). Pelatihan Pembukuan Sederhana Bagi UMKM Menuju UMKM Naik Kelas Di Kecamatan Grogol. Jurnal Pengabdian Dan Peningkatan Mutu Masyarakat (JANAYU), 1(2), 109-116. https://doi.org/10.22219/janayu.v1i2. 12143

Purwanto, A., Maricar, M. A., Sukerti, N.
K., \& Nugroho, A. (2020). Pelatihan dan Pendampingan Pencatatan Pembukuan Keuangan dan Pembuatan Website Bengkel Waras Motor Denpasar. WIDYABHAKTI Jurnal Ilmiah Populer, 3(1), 13-17. https://doi.org/10.30864/widyabhakti. v3i1.216

Ramdani, D., Merinda, Hendrani, A., \& Suherli. (2020). Akuntansi Biaya. Yogyakarta: CV Markumi.

Republik Indonesia. (2008). UndangUndang Nomor 20 Tahun 2008 tentang Usaha Mikro, Kecil dan Menengah (UMKM).

Riwayadi. (2016). Akuntansi Biaya. Jakarta: Salemba Empat.

Rudianto. (2013). Akuntansi Manajemen Informasi untuk Pengambilan Keputusan Strategis. Jakarta: Erlangga.

Saleh, M. Y., \& Said, M. (2019). Konsep dan Strategi Pemasaran. Makasar: CV Sah Media.

Siregar, B., Suripto, B., Haposro, D., Lo, E. W., Herowati, E., Kusumasari, L., \& Nurofik. (2013). Akuntansi Biaya. Jakarta: Salemba Empat.

Kontan. (2020). Ada 1.785 koperasi dan 16.313 UMKM terdampak pandemi Covid-19. Diakses tanggal 11 Februari 2021 dari https://keuangan.kontan.co.id/news/a da-1785-koperasi-dan-16313-umkmterdampak-pandemi-Covid-19. 